\title{
O Campo da Atenção à Saúde Após a Constituição de 1988: uma Narrativa de sua Produção Social.
}

Maria Ceci Misoczky. Porto Alegre: Dacasa Editora/PDGSaúde, 2002. 191 p. ISBN 8586072435.

por Ronaldo Bordin

(Faculdade de Medicina - Departamento de Medicina Social - UFRGS)

Este livro decorre de uma tese de doutorado apresentada pela autora ao PPGAUFRGS. Ainda que se origine de um trabalho produzido para obtenção de um título acadêmico, não espere encontrar o formato tradicional e o texto que vem de lugar nenhum. Pelo contrário, o texto é extremamente situado, autoral e posicionado. Aliás, caso não fosse assim, este seria um caso típico de incoerência entre teoria e forma. Isto porque a autora afirma, desde o início, a necessidade de superar o paradigma funcionalista hegemônico como condição indispensável para exercitar o princípio ético crítico adotado - uma ética centrada no valor da liberdade e da vida, que vê na materialidade negada da produção, reprodução e desenvolvimento da vida humana em comunidade o fundamento da crítica social. A partir dessa postura, baseada nas formulações de Enrique Dussel (2001), a autora vai buscar uma atitude filosófica que seja coerente, encontrando-a na hermenêutica gadameriana; uma metodologia de pesquisa que não mutile o objeto a partir de pré-concepções do senso comum, encontrando-a no construcionismo; e teorias que lhe permitam aproximar-se do objeto de estudo de modo reflexivo e crítico, encontrando-a em sua elaboração pessoal a partir das formulações de Pierre Bourdieu e de Carlos Matus.

A construção teórica realizada é bastante complexa, misturando diversos campos de conhecimento. Trata-se de um texto que se localiza no campo das novas humanidades, recusando o sistema de disciplinas, explorando interdições, levando a sério problemas anulados pelas disciplinas dominantes.

O livro se constrói aos poucos. Encontra-se, primeiro, uma apresentação dos caminhos para compreender e da opção pelo construcionismo hermenêutico. Esta opção decorre da decisão de enfatizar a ação social e da adoção da noção de produção social. Se a suposição central do estudo é que a realidade é construída por atores sociais em interação só resta o caminho da perspectiva construcionista, que afirma que tanto o sujeito como o objeto, tanto o conhecimento quanto os critérios de validação, todos resultam de processos de construção social. A ênfase na hermenêutica gadameriana, por sua vez, se deve ao reconhecimento de que 
verdade e significado se referem a operações criativas por parte do entendimento humano, que é sempre interpretativo e nunca simplesmente representacional. Daí decorre a linha de coerência que orienta a narrativa que se seguirá: a historicidade, a mediação da linguagem e a interpretação como diálogo.

Já para produzir seu texto, a autora adota a vertente hermenêutica crítica, para quem a narrativa é o modo através do qual organizamos nossa experiência do tempo como uma fusão do passado, do presente e do futuro. Para que uma narrativa se constitua, é indispensável a existência de uma intriga, entendida - a partir de Aristóteles - como a unidade inteligível que conjuga circunstâncias, cenas, atores, finalidades, meios, iniciativas e conseqüências. Aqui, talvez, a construção mais interessante do livro: a organização da intriga em torno da disputa pela definição de conceitos.

A narrativa do livro será, então, construída em torno dos atores sociais em interação que, a partir de seus interesses específicos, recursos de poder e posicionamento, disputam a definição dos conceitos que configuram o espaço de posições do campo da atenção à saúde - direito e descentralização. Aqui é importante destacar que a autora tem uma longa trajetória nesse campo, o que certamente lhe permitiu perceber que ocorriam mudanças de rumo na trajetória da formação da política de saúde sem que os princípios formalmente declarados tivessem se alterado. Para aproximar-se dos textos, e desopacificá-los, a autora utiliza a análise crítica de discurso.

Algumas palavras sobre a construção do objeto de pesquisa. Tradicional e hegemonicamente, a saúde tem sido tratada, no contexto brasileiro, segundo o modelo sistêmico. Assim, o primeiro passo de Maria Ceci, no sentido de romper com a doxa, é o de realizar uma breve desconstrução desse modelo, considerando tanto suas implicações para a organização da atenção à saúde quanto, principalmente, suas conseqüências para a análise de políticas públicas. Como alternativa escolhe a representação do objeto através da imagem de campos de poder. O campo, segundo Bourdieu (1996), é compreendido como um espaço de posições, entre atores sociais, em uma relação de mútua exclusão. O campo é uma construção empírica, só podendo ser descrito a partir de critérios que precisam dar conta de um conjunto de diferenças que separam os atores e que permitem que um conjunto de relações apareça. O campo é definido pela especifidade da luta e por aquilo que nele está em jogo.

A pesquisa que constitui o foco do livro foi, então, organizada a partir de uma série de escolhas: rejeitar o modelo sistêmico e buscar alternativas; identificar a potencialidade da concepção de campo de poder para compreender fenômenos sociais; analisar as relações de poder que ocorrem no campo; identificar os 
conceitos centrais cuja definição é disputada - direito à saúde e descentralização; identificar quais as definições dominantes, quais atores sociais estavam interessados no jogo e como se posicionavam; seguir a trajetória da relação entre os atores posicionados; identificar os atores e as posições a partir das suas ações discursivas, que foram sendo registradas ao longo da narrativa; sintetizar as acumulações resultantes, principalmente sob a forma de leis e normas que objetivam uma determinada definição conceitual.

Não pretendi apresentar os resultados do estudo, reproduzir a narrativa. Considerei mais adequado, dado o foco da RAC, interessá-los pela construção teórico-metodológica realizada pela autora. Não apenas por algumas novidades, considerando o contexto brasileiro da administração, mas pelo cuidado, coerência e autenticidade com que isto foi realizado. Assim, mesmo que você não se interesse por política de saúde ou por administração pública, este livro traz uma interessante e relevante contribuição para os estudos organizacionais brasileiros, considerando sua qualidade teórica e seus aspectos inovadores.

\section{REFERÊNCIAS}

BOURDIEU, P.

Razões práticas: sobre a teoria da ação. Campinas: Papirus, 1996.
DUSSEL, E. Hacia una filosofía política crítica. Bilbao: Desclée de Broker, 2001. 